\title{
Hydro-microbiological attributes of the soil in edge of seasonal semideciduous forest fragment
}

\author{
Karolayne Lemes D'Abadia ${ }^{1}$, Ane Gabriele Vaz Souza', Gabriela Gomes da Silva ${ }^{1}$, Murilo \\ Silva Machado', Vagner Santiago do Vale ${ }^{1}$, Talles Eduardo Borges dos Santos ${ }^{1}$ \\ ${ }^{1}$ Universidade Estadual de Goiás, Campus Ipameri, Ipameri, Goiás, Brasil. E-mail: karolldab@gmail.com, anevazsouza@ gmail.com, \\ gabrielasilvagomes2016@gmail.com, murilomachado2310@outlook.com,vsvale@hotmail.com, tallesunesp@yahoo.com.br
}

Received: 31/08/2019; Accepted: 04/03/2020.

\begin{abstract}
Native forests have been suffering changes, such as fragmentation and edge effect, and these have implications for the dynamics of carbon within the same fragment, differentiating vegetation and soil. In this way, the work aimed to evaluate the hydro-microbiological attributes of the soil in rainy and dry periods, as well as to indicate if there is an edge effect in a seasonal semideciduous forest fragment. The study was carried out in a forest fragment in the area of the State University of Goiás, Ipameri Campus, consisting of three transects divided into three blocks from the edge. Sampling was performed in two periods of the year, rainy and dry, to determine the gravimetric soil water content (UG), microbial biomass carbon (MBC), basal respiration (BR), and the metabolic quotient $\left(q \mathrm{CO}_{2}\right)$. The data were subjected to analysis of variance ( $F$ test), and when significant, the means were evaluated by the Tukey test at $5 \%$ probability. Response variations of microorganisms are closely related to the periods studied; the rainy season benefits the carbon incorporation activity, and the dry season stimulates the carbon release. Consequently, metabolic efficiency is more pronounced in the rainy season. The edge of the fragment only influenced the MBC, evidencing that disturbances caused at the extremity of fragment interfere with the $\mathrm{C}$ input in the microbial biomass.
\end{abstract}

Keywords: Native forests, Microbiology, Fragmentation effect, Microbial carbon.

\section{Atributos hídrico-microbiológicos do solo em borda de fragmento florestal estacional semidecidual}

\section{RESUMO}

As florestas nativas vêm sofrendo alterações, como fragmentação e efeito de borda, sendo que estes apresentam implicações sobre a dinâmica do carbono dentro de mesmo fragmento, diferenciando vegetação e solo. Deste modo, o trabalho teve como objetivo avaliar os atributos hídrico-microbiológicos do solo em período chuvoso e seco, assim como indicar se há efeito de borda em um fragmento florestal estacional semidecidual. O estudo foi realizado em um fragmento florestal na área da Universidade Estadual de Goiás, Campus Ipameri, constando de três transectos divididos em três blocos de distância da borda. Realizou-se amostragem em dois períodos do ano, chuvoso e seco, para determinação da umidade gravimétrica (UG), do carbono da biomassa microbiana (CBM), da respiração microbiana $(\mathrm{RM})$ e do quociente metabólico $\left(q \mathrm{CO}_{2}\right)$. Os dados foram submetidos à análise de variância (teste F), e quando significativa, as médias foram avaliadas pelo teste de Tukey a 5\% de probabilidade. Variações de resposta dos microrganismos estão intimamente relacionadas com os períodos estudados; o período chuvoso beneficia a atividade de incorporação de carbono e o período seco estimula liberação de carbono. Consequentemente, a eficiência metabólica é mais pronunciada no período chuvoso. A borda do fragmento apenas exerceu influência sobre o CBM, demostrando que distúrbios causados na extremidade do fragmento interferem no aporte de $\mathrm{C}$ na biomassa microbiana.

Palavras-chave: Florestas nativas, Microbiologia, Efeito da fragmentação, Carbono microbiano. 


\section{Introduction}

Forests are the most responsible for capturing the carbon dioxide present in the Earth's atmosphere. This process occurs through photosynthesis, where part of the $\mathrm{CO}_{2}$ is incorporated by the plants and stored in their plant biomass (Figueiredo et al., 2015). The other part returns to the atmosphere. There is a fundamental difference between the different carbon storage structures: tropical forests contain $56 \%$ carbon in their plant biomass and $32 \%$ in the soil (Pan et al., 2011).

Soil $\mathrm{CO}_{2}$ can show high levels of organic carbon (CO), and to attenuate the emission of carbon dioxide into the atmosphere (Cunha et al., 2010). Microbial biomass is considered as the labile fraction of soil organic matter (SOM), it may reflect changes in organic matter (OM), as well as in soil development since microorganisms act in various processes that compromise the ecosystem and are related to soil fertility, nutrient cycling, variations in carbon stocks and OM dynamics (Hoffmann et al., 2018).

The proper management and use of the soil contribute to the reduction of greenhouse gases, favoring the accumulation of carbon and the maintenance of the soilplant system, softening the adverse effects on the environment (Costa et al., 2015). Soils can contain twice as much carbon (C) compared to the atmosphere. However, they can change according to the form of land use, climate and management, and can have significant losses, varying between 25 and $75 \%$ of C (Primieri et al., 2017).

The increase in human activities have transformed the original forest cover; as a result of these processes, there is a suppression in areas of native vegetation and the formation of forest fragments (Santos et al., 2019). One of the main consequences caused by these processes is the edge effect, which, according to Figueiró (2015) and Campos et al. (2018), can cause loss of biodiversity and physical and structural changes at the edge of the fragment. The edge effect causes greater separation between stretches of natural ground cover, reducing the size of the connection fragments between one forest and another, with negative consequences on the movement of organisms and matter (Mitchell et al., 2015).

From the limit of the fragments towards the interior of the forest, there are changes in the structure and functioning of the forest ecosystem (Lima et al., 2017). The edges have biotic and abiotic characteristics distinct from its core, mainly greater exposure to winds, reduced humidity, high light incidence, and consequently high temperatures (Lima-Ribeiro, 2008).

All these factors interfere with microbial biomass, considered a living part of organic matter, composed of the entire community of fungi, bacteria, actinobacteria, and algae (Silva et al., 2012). They stand out for being highly sensitive to the physical-chemical indicators
(Trannin et al., 2007) and for acting directly in the decomposition processes of organic material, thus acting in the biogeochemical cycle of soil nutrients (Jacinto et al., 2018). The climatic variables are linked to the flow of $\mathrm{CO}_{2}$ into the atmosphere, the main factors for emissions being the temperature (of the air and soil), and the humidity of the soil, through their relationship with the topographic conditions of the place (Silva et al., 2019).

The biological properties of the soil are related in different ways in different areas and periods (Novak et al., 2018), that is, the type of soil in the region, climate, vegetation and anthropic action act on the quantity, diversity, and quality of the carbon present in the soil. Thus, the assessment of the microbial biomass carbon (MBC) and basal respiration (BR) are important subsidies to better understand the dynamics of the transformation processes of organic waste in the soil (Segatto et al., 2012). However, the interpretation of these assessments in isolation is not always satisfactory as an indicator of improvement in soil quality. For these parameters, the MBC analysis of the soil indicates the amount of carbon immobilized in the microbial cells. The $\mathrm{BR}$ analysis allows evaluating the amount of $\mathrm{CO}_{2}$ released by the activity of microorganisms (Alves et al., 2011). The $q \mathrm{CO}_{2}$ expresses the relationship between the quantity of existing MBC and the RM (Mendes et al., 2009), where the analyzes must present low values of $q \mathrm{CO}_{2}$ (Quadro et al., 2011), since, when high values for this parameter are shown, it means a rapid loss of carbon in the form of $\mathrm{CO}_{2}$, with little efficiency in its use through microorganisms (Silva et al., 2012).

Given the above, the microbiological fraction presents itself as a strong indicator of disturbances, making it possible to obtain information on the change in its dynamics with the entry in a forest fragment. In this way, the work aimed to evaluate the hydromicrobiological attributes of the soil in rainy and dry periods, as well as to indicate if there is an edge effect in a seasonal semideciduous forest fragment.

\section{Material and Methods}

The study was carried out in a forest fragment of the experimental farm of the State University of Goiás, Ipameri Campus, geographically located at $17^{\circ} 43^{\prime} 07^{\prime \prime} \mathrm{S}$, $48^{\circ} 08^{\prime} 42^{\prime \prime} \mathrm{W}$, and an average altitude of $781 \mathrm{~m}$. The climate of the region is tropical Semi-humid (Aw) according to the Koppen classification, with an average temperature of $21.9{ }^{\circ} \mathrm{C}$, relative humidity between $58 \%$ and $81 \%$, and around $1,447 \mathrm{~mm}$ of annual precipitation. (Alvares et al., 2013). The soil was classified as Latossolo Vermelho-Amarelo distrófico (Embrapa, 2018) of medium texture or Oxisol (Soil Survey Staff, 2014) (Table 2), inserted within the Cerrado biome. 
Table 1. Chemical and textural characteristics of the soil in the $0-0.10 \mathrm{~m}$ layer.

\begin{tabular}{|c|c|c|c|c|c|c|c|c|c|}
\hline \multirow{3}{*}{$\begin{array}{c}\text { P Melich } \\
\left({\left.\mathrm{g} . \mathrm{dm}^{-3}\right)}^{-}\right. \\
3,7\end{array}$} & \multirow{3}{*}{$\begin{array}{c}\mathrm{MO} \\
\left(\mathrm{g} \cdot \mathrm{dm}^{-3}\right) \\
35,0\end{array}$} & \multirow{3}{*}{$\begin{array}{c}\mathrm{pH} \\
\left(\mathrm{CaCl}_{2}\right) \\
4,7\end{array}$} & $\mathrm{~K}$ & $\mathrm{Ca}$ & $\mathrm{Mg}$ & $\mathrm{Al}$ & $\mathrm{H}+\mathrm{Al}$ & CTC & \multirow{3}{*}{$\begin{array}{c}\mathrm{V} \\
(\%) \\
55,13\end{array}$} \\
\hline & & & \multicolumn{6}{|c|}{$\mathrm{cmol}_{c} \cdot \mathrm{dm}^{-3}$} & \\
\hline & & & 0,52 & 4,4 & 1,1 & 0,1 & 4,9 & 10,92 & \\
\hline \multicolumn{3}{|c|}{ Clay } & \multicolumn{4}{|c|}{ Silt } & \multicolumn{3}{|c|}{ Sand } \\
\hline \multicolumn{3}{|c|}{$\left(\right.$ g. $\left.\mathrm{kg}^{-1}\right)$} & \multicolumn{3}{|c|}{$\left(\mathrm{g} \cdot \mathrm{kg}^{-1}\right)$} & & \multicolumn{3}{|c|}{$\left(\right.$ g. $\left.\mathrm{kg}^{-1}\right)$} \\
\hline \multicolumn{3}{|c|}{260,0} & \multicolumn{3}{|c|}{180,0} & & \multicolumn{3}{|c|}{560,0} \\
\hline
\end{tabular}

Medium texture.

The forest fragment studied is an edge of Seasonal Semideciduous Forest (SSF). Three horizontal transects, $90 \mathrm{~m}$ long and $10 \mathrm{~m}$ wide were implanted, demarcated with iron stakes and string tape to carry out the sampling. In each transect, nine plots were plotted from the edge of the forest towards the interior (Figure 1). The sampling area of each demarcated transect corresponded to $900 \mathrm{~m}^{2}$, thus resulting in plots of $100 \mathrm{~m}^{2}$ and a total sample area of $0.36 \mathrm{ha}$. The distance between the transects was $50 \mathrm{~m}$, measured from the reference line, on the outside of the fragment.

In each plot, ten soil samples were randomly collected with the aid of a hoe, to form a composite sample at depth $0-10 \mathrm{~cm}$. This process was carried out in all plots for the two periods of the year. The first period in April 2018, considered as the end of the rainy season. The second at the beginning of October 2018, viewed as the end of the dry period. The collected samples were kept in Styrofoam boxes and cooled during transport to the laboratory, where they were homogenized and passed through a $2 \mathrm{~mm}$ mesh sieve. Part of it was removed for moisture analysis, and the rest was stored in a refrigerator at a temperature of $7( \pm 3)$ ${ }^{\circ} \mathrm{C}$ until the following day when the microbiological analysis was started. The determination of gravimetric soil water content $(\theta \mathrm{g})$ consists of weighing the mass of moist soil (mwet) and then drying it in an oven at $105-110^{\circ} \mathrm{C}$ for 24 hours, determining its dry mass (mdry). From the data, it is obtained the gravimetric soil water content according to the equation $\theta \mathrm{g}=[($ mwet-mdry $) /$ mdry $] * 100$ (Matsunaga et al., 2018).

The microbial biomass carbon (MBC) was obtained by the irradiation-extraction method (Mendonça and Matos, 2005), which consists of the use of electromagnetic energy (microwave), causing an effect on the transfer of energy and temperature, leading to a cell disruption with the release of intracellular compounds. The extraction was carried out with potassium sulfate $0.5 \mathrm{~mol} \mathrm{~L}-1$, oxidation with $0.066 \mathrm{~mol}$ $\mathrm{L}^{-1}$ potassium dichromate, and titration with $0.033 \mathrm{~mol} \mathrm{~L}$ ${ }^{1}$ ferrous ammonium sulfate. Basal respiration (BR) was estimated by the amount of $\mathrm{CO}_{2}$ released from the soil, for four days of incubation, with the values expressed in $\mathrm{mg} \mathrm{C}-\mathrm{CO}_{2} \mathrm{~kg}^{-1}$ of soil day ${ }^{-1}$. The metabolic quotient $\left(q \mathrm{CO}_{2}\right)$ was calculated by the ratio between BR and MBC (Anderson and Domsch, 1993).

The data for each variable ( $\mathrm{MBC}, \mathrm{BR}, q \mathrm{CO}_{2}$, and $\theta \mathrm{g}$ ) were submitted to the Lilliefors normality test, being considered normal ( $p>0.05)$. Analysis of variance (test $F$ ) was performed to determine the effect of the period of the year, distance to the edge, and interaction between these factors. When significant, the means comparison test was performed using the Tukey test at 5\% probability, with the aid of the SISVAR statistical software, version 5.6 (Ferreira, 2019).

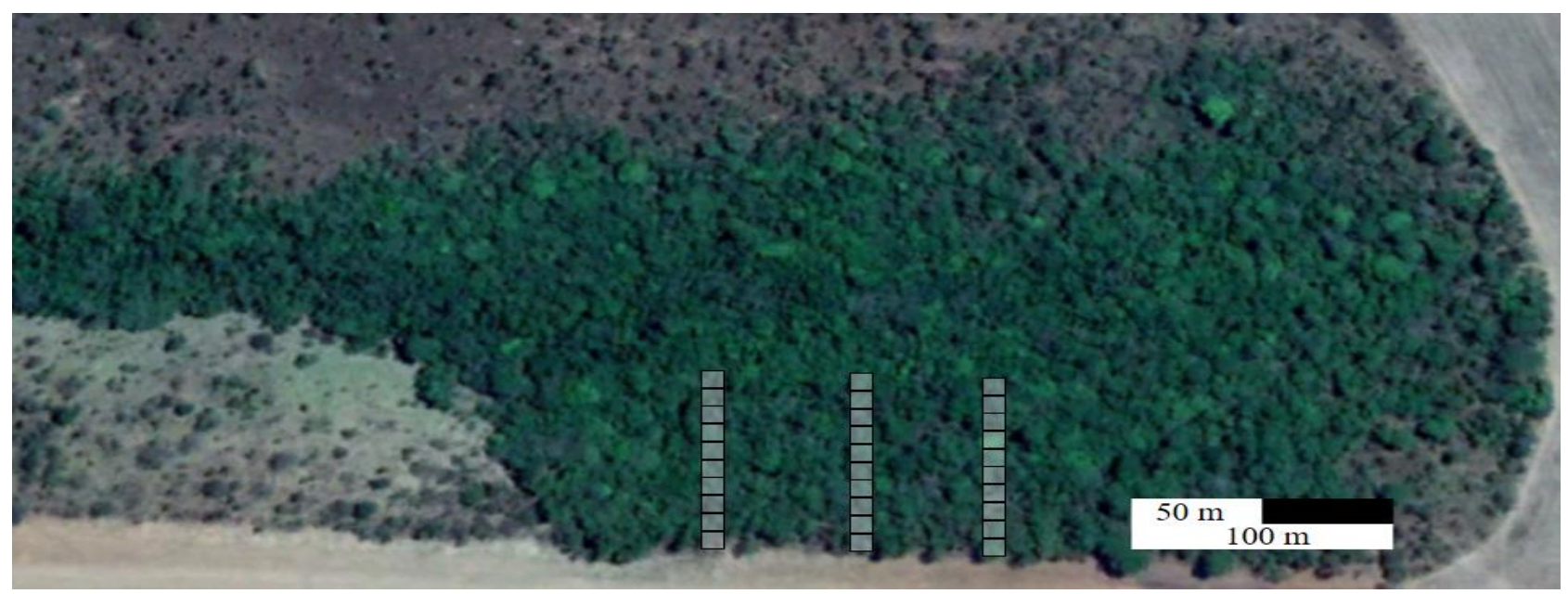

Figure 1: Demonstrative sketch of the transects within the Seasonal Semideciduous Forest (SSF). 
The variables that had a significant effect on the analysis of variance were subjected to regression analysis using simple, logarithmic, and parabolic models to assess the distance from the edge. The model that best matched the data was chosen, as it has the highest determination coefficient.

\section{Results and Discussion}

There was no interaction between the periods of the year and the distance from the edge. Exception for gravimetric soil water content, the results of the analysis of variance showed that the period of the year provided significant differences in all another microbiological variable of the evaluated soils (Table 2). For the distance from the edge, only the microbial biomass carbon had a significant result.

For the microbial biomass carbon, the rainy period was higher than the dry period (Figure $2 \mathrm{~A}$ ), that is, there was higher storage of $\mathrm{C}$ in the rainy period. In a study by Araujo et al. (2008) aiming to evaluate the microbial activity through the production of $\mathrm{C}-\mathrm{CO}_{2}$ in a watershed, in the semi-arid region of Paraíba; a decrease in the release of $\mathrm{C}-\mathrm{CO}_{2}$ was observed from January to March and from May to July, periods with the presence of rainfall, which contributed to the increase in carbon sequestration by vegetation and soil microbiota. This statement corroborates the prolonged drought simulation experiment in the Amazon rainforest, to observe the behavior of microorganisms, in which Matsunaga et al. (2018) found higher levels of MBC in the rainy season, as well as in the transition period from the dry to the rainy season.

Basal respiration was higher in the dry period (Figure 2B). Araújo et al. (2007) and Silva et al. (2016) emphasize that high temperature and low humidity can favor the microbial activity of the soil, as well as influence the decomposition time of the organic material existing under the soil, thus increasing the release of $\mathrm{CO}_{2}$ due to the basal respiration to the atmosphere. As well as basal respiration (Figure 2B), the metabolic quotient
(Figure 2C) showed higher values in the dry period, mainly resulting from the loss of $\mathrm{C}-\mathrm{CO}_{2}$ through the intense activity of microorganisms, demonstrating that this period provides an environment unfavorable to the soil microorganisms. The change of seasons throughout the year provided an inversion in the population arrangement of microorganisms in the soil depths, with the highest basal respiration values observed in the least rainy season, meeting at a depth of 0.2-0.3 $\mathrm{m}$ (Matsunaga et al., 2018). According to Matsunaga et al. (2018), this change generates a disturbance due to the movement of these organisms to the region of greater thermal comfort, due to the shift to the less rainy period.

Generally, high values of $q \mathrm{CO}_{2}$ are associated with stressful environmental conditions, in which soil microbial biomass spends more $\mathrm{C}$ for maintenance (Souza et al., 2010). Given these facts, it can be inferred that in the dry season, there was less efficiency in incorporating the carbon stock in the cells and higher activity of microorganisms. That is, there is a higher amount of carbon being released in the form of $\mathrm{CO}_{2}$, determining that this microbiota is made it less efficient in carrying out its processes (Andrade et al., 2016). Pondering the constitution of the soil microbiota, an efficient community would have a low rate of respiration (Santana et al., 2017).

With the increase in the distance from the fragment's edge towards to interior, there was an increase in the carbon concentrations of the microbial biomass at a depth of $0.0-0.10 \mathrm{~m}$ (Figure 3 ). That is, the closer to the interior of the seasonal semideciduous forest fragment, the greater it was the incorporation of carbon by the local microbiota. Abiotic factors (temperature, humidity, wind) caused by the edge effect, possibly also provide a decrease in the amount of existing organic matter and its decomposition, as verified by Dernardin et al. (2014) in a study evaluating the potential of $\mathrm{C}$ accumulation in the soil in different forest formations. In these conditions, if deposition of organic material occurs at the edges of the fragments, the lower the carbon subsidy for aggregation by microorganisms will be.

Table 2. F-values microbial biomass carbon (MBC), Basal respiration (BR), metabolic quotient $\left(q \mathrm{CO}_{2}\right)$, gravimetric soil water content $(\theta \mathrm{g})$ in the rainy and dry period, at different distances from the edge of a seasonal semideciduous forest fragment.

\begin{tabular}{cccccc}
\hline Source of Variation & DF & MBC & BR & $q \mathrm{CO}_{2}$ & $\theta \mathrm{g}$ \\
\hline & \multicolumn{5}{c}{ Simple effect } \\
\cline { 2 - 6 } Period (P) & 1 & $181.800^{* *}$ & $429.660^{* *}$ & $151.860^{* *}$ & $0.088^{\mathrm{ns}}$ \\
Distance (D) & 8 & $2.960^{*}$ & $1.912^{\mathrm{ns}}$ & $1.283^{\mathrm{ns}}$ & $1.420^{\mathrm{ns}}$ \\
\cline { 2 - 6 } & \multicolumn{5}{c}{ Interaction } \\
\cline { 2 - 6 } P x D & 8 & $0.675^{\mathrm{ns}}$ & $0.625^{\mathrm{ns}}$ & $1.095^{\mathrm{ns}}$ & $1.040^{\mathrm{ns}}$ \\
\hline Total & 17 & - & - & - & 14.13 \\
\hline CV $(\%)$ & & 20.95 & 14.35 & 44.44 \\
\hline
\end{tabular}

${ }^{* *}$ and ${ }^{*}$ significant at 1 and $5 \%$ probability by the $\mathrm{F}$ test, respectively. ${ }^{\mathrm{ns}}$ not significant. CV: coefficient of variation; DF: degrees of freedom. 

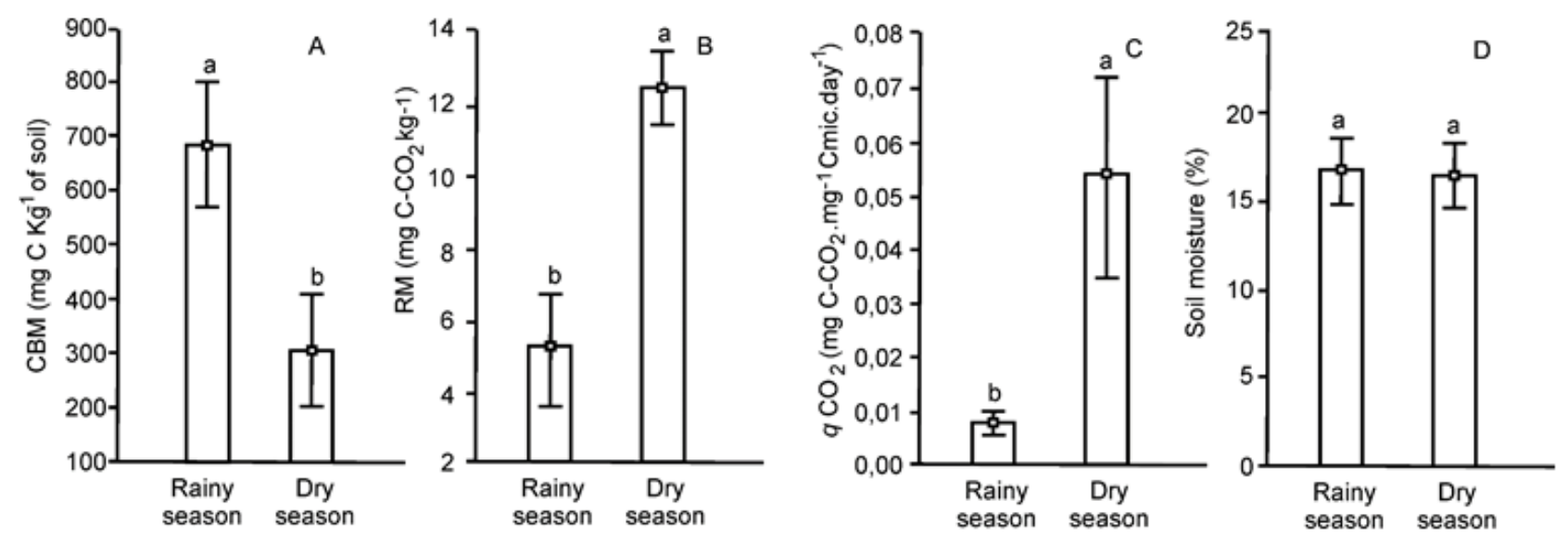

Figure 2. Microbial biomass carbon - $\mathrm{MBC}(\mathrm{A})$, basal respiration - BR (B), metabolic quotient - $q \mathrm{CO}_{2}(\mathrm{C})$, and gravimetric soil water content $-\theta g(D)$ in the rainy and dry period in a seasonal semideciduous forest fragment. Letters differ from each other, showing a significant result between the two periods studied, at the level of $1 \%$ by the Tukey test.

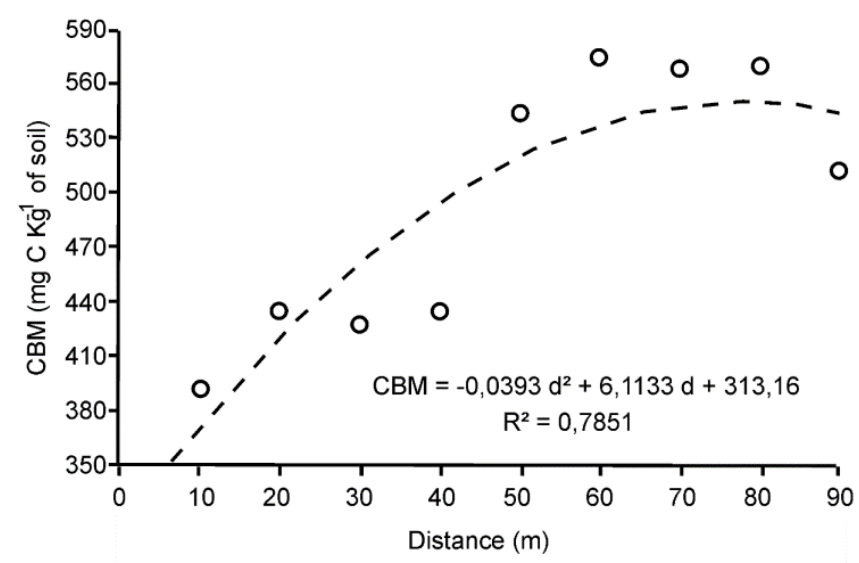

Figure 3. Regression equation of the microbial biomass carbon in the $0-0.10 \mathrm{~m}$ layer according to the distances from the edge in a seasonal semideciduous forest fragment.

The edge effect was not found for the variables BR, $q \mathrm{CO}_{2}$, and $\theta \mathrm{g}$, a fact that may be related to the type of vegetation found in the environment. Since there was no change in the composition of the material present with the entry in the fragment, also, there was no influence on the activity of the local biological community, thus not altering its activity.

The evaluations on the effect of different cultivation systems in the Cerrado under physical soil properties found a difference between the crops when evaluating the water content in the soil. The native vegetation had a higher water content in the soil during the drought period, which can be explained due to the soil cover, which favors the preservation of moisture, reducing evaporation (Gomes et al., 2015). This fact can be associated with the present study, since there was no considerable variation in vegetation, with no significant changes in soil moisture.

\section{Conclusions}

The carbon dynamic by microorganisms is closely related to the periods studied, with the rainy season benefiting the $\mathrm{C}$ incorporation activity, and the dry period stimulating the release in the form of $\mathrm{C}-\mathrm{CO}_{2}$. The effect of the edge of the fragment influenced MBC, showing that disturbances caused at the extremity of fragment interfere with the inclusion of $\mathrm{C}$ in the biomass of microorganism.

\section{Bibliographic References}

Alvares, C.A., Stape, J.L., Sentelhas, P.C., Gonçalves, J.L.D.M., Sparovek, G., 2013. Koppen's climate classification map for Brazil. Meteorologische Zeitschirtf, 22(6), 711-728.

Alves, T.S., Campos, L.L., Neto, N.E., Matsuoka, M., Loureiro, M.F., 2011. Biomassa e atividade microbiana de solo sob vegetação nativa e diferentes sistemas de manejos. Acta Scientiamm. Agronomy, 33(2), 341-347. 
Anderson, T.H, Domsch, K.H., 1993. Ratios of microbial biomass carbon to total organic carbon in arable soils. Soil Biology and Biochemistry, 21(4), 471-479.

Andrade, L.C., Andreazza, R., Camargo, F.A.O., 2016. Atividade microbiana em solos sob doses de lodo de estação de tratamento de efluentes de aterro industrial. Ciência Rural, 46(2), 267-272.

Araújo, K.D., Andrade, A.P., Raposo, R.W.C., Rosa, P.R.O., Pazera Junior, E., 2007. Perdas de $\mathrm{CO}_{2}$ do solo e variabilidade temporal das condições climáticas no semiárido paraibano. Raega - O Espaço Geográfico em Análise, 13(13), 99-107.

Araujo, K.D., Andrade, A.P., Rosa, P.R.O., Bruno, R.L.A., Fraga, V.S., 2008. Avaliação da atividade microbiana baseada na produção de $\mathrm{C}-\mathrm{CO}_{2}$ em uma área de Caatinga no Cariri Paraibano. Caatinga, 21(3), 221-230.

Campos, J.O., Santos, J.S., Salvador, M.S.S., Lima, V.R.P., 2018. Análise e propagação dos efeitos de borda no Parque Estadual Mata do Pau-Ferro, Areia-PB. Revista Geográfica Acadêmica, 34(2), 21-36.

Costa, N.R., Andreotti, M., Lopes, K.S.M., Yokobatake, K., Ferreira, J.P., Pariz, C.M., Bonono, S.B., Longhini, V.Z., 2015. Atributos do solo e acúmulo de carbono na integração lavourapecuária em sistema plantio direto. Revista Brasileira de Ciências do Solo, 39(3), 852-863.

Cunha, T.J.F., Novotny, E.H., Madari, B.E., Benites, V.M., Martin Neto, L., Santos, G.A.O., 2010. Carbono Pirogênico, in: Teixeira, W.G., Kern, D.C., Madari, B.E., Lima, H.N., Woods, W., (Ed.). As terras pretas de índio da Amazônia: sua caracterização e uso deste conhecimento na criação de novas áreas. Manaus, Embrapa Amazônia Ocidental.

Dernardin, R.B.N., Mattias, J.L., Wildner, L.P., Nesi, C.N., Sordi, A., Kolling, D.F., Busnello, F.J., Cerutti, T., 2014. Estoque de carbono no solo sob diferentes formações florestais, Chapecó-SC. Ciência Florestal, 24(1), 59-69.

Embrapa, 2018. Sistema brasileiro de classificação de solos, quinta ed. Brasília, Embrapa Solos.

Ferreira, D.F., 2019. SISVAR: a computer analysis system to fixed effects split plot type designs. Revista Brasileira de Biometria, 37(4), 529-535.

Figueiredo, L.T.M., Soares, C.P.B., Souza, A.L., Leite, H.G., Silva, G.F., 2015. Dinâmica do estoque de carbono em fuste de árvores de uma floresta estacional semidecidual. Cerne, 21(1), 161-167.

Figueiró, A.S., 2015. Biogeografia: dinâmicas e transformações da natureza, primeira ed. São Paulo, Oficina de Textos.

Gomes, R.L.R., Silva, M.C., Costa, F.R., Junior, A.F.L., Oliveira, I.P.O., Silva, D.B., 2015. Propriedades físicas e teor de matéria orgânica do solo sob diferentes coberturas vegetais. Resvista Faculdade Montes Melos (FMB), 8(5), 72-139.

Hoffmann, R.B., Moreira, É.E.A., Hoffmann, G.S.S., Araújo, N.S.F., 2018. Brazilian Journal of Animal and Environment Research, 1(1), 168-178.
Jacinto, H.R., Moura, J.B., Uto, F.N., 2018. Avaliação da influência atrópica sobre a microbiota edáfica de cerrado no município de Anápolis, Goiás. Agronomic Journal, 2(2), 4-17.

Lima, B.C., Francisco, C.N., Bohrer, C.B.A., 2017. Deslizamentos e fragmentação florestal na região serrana do estado de Rio de Janeiro. Ciência Florestal, 27(4), 1283-1295.

Lima-Ribeiro, M.S., 2008. Efeitos de borda sobre a vegetação e estruturação populacional em fragmentos de Cerradão no Sudoeste Goiano, Brasil. Acta Botanica Brasilica, 22(2), 535545.

Matsunaga, W.K., Rodrigues, H.J.B., Rodrigues, P.G., 2018. Atributos microbiológicos de solo, relacionados às atividades da microfauna em solo na floresta Amazônica. Anuário do Instituto de Geociências - UFRJ, 41(3), 630-638.

Mendes, I.C., Hungria, M., Junior, F.B.R., Fernandes, M.F., Chaer, G.M., Mercante, F.M., Zilli, J.E., 2009. Bioindicadores para Avaliação da Qualidade dos Solos Tropicais: utopia ou realidade? Planaltina, DF: EMBRAPA Cerrados, 31 p. (Embrapa Cerrados. Documentos 246).

Mendonça, E.S., Matos, E.S., 2005. Matéria orgânica do solo: métodos de análises. Viçosa, MG, Universidade Federal de Viçosa, 107 p.

Mitchell, M.G.E., Suarez-Castro, A.F., Martinez-Harms, M., Maron, M., Mcalpine, C., Gaston, K.J., Johansen, K., Rhodes, J.R., 2015. Reframing landscape fragmentation's effects on ecosystem services. Trends in Ecology \& Evolution, 30(4), 190-198.

Novak, E., Carvalho, L.A., Santiago, E.F., Brumatti, A.V., Santos, L.L., Sales, L.C., 2018. Variação temporal dos atributos microbiológicos do solo sob diferentes usos. Revista de Ciências Agrárias, 41(3), 603-611.

Pan, Y., Birdsey, R.A., Fang, J., Houghton, R., Kauppi, P.E., Kurz, W.A., Phillips, O.L., Shvidenko, A., Lewis, S.L., Canadell, J.G., Ciais, P., Jackson, R.B., Pacala, S.W., McGuire, A.D., Piao, S., Rautiainen, A., Sitch, S., Hayes, D., 2011. A large and persisitent carbon sink in the world's forests. Science, 333(6045), 988-993.

Primieri, S., Muniz, A.W., Lisboa, H.M., 2017. Dinâmica do carbono no solo em ecossistemas nativos e plantações florestais em Santa Catarina. Floresta e Ambiente, 24, 1-9.

Quadro, M.S., Castilhos, D.D., Castilhos, R.M.V., Vivian, G., 2011. Biomassa e atividade microbiana em solo acrescido de dejeto suíno. Revista Brasileira de Agrociência, 17(1-4), 85-93.

Santana, A.S., Chaves, J.S., Santana, A.S., Rodríguez, C.A., Moraes, E.R., 2017. Biomassa microbiana em diferentes sistemas de manejo do solo no sul do estado de Roraima. RBCA, 1(1), 1-62.

Santos, M.O.D., Barreto-arcia, P.A.B., Gama-Rodrigues, E.F., 2019. Soil microbial biomass as an edge effect indicator in semi-deciduous seasonal forest fragments. Floresta e ambiente, 26(4), e20171037.

Segatto, M.P., Andreazza, R., Bortolon, L., Santos, V.P., Gianello, C.E., Camargo, F.A.O., 2012. Decomposição de resíduos industriais no solo. Ciência e Natura, 34(1), 49-62. 
Silva, D.A.P., Campos, M.C.C., Mantovanelli, B.C., Santos, L.A.C., Soares, M.D.R., Cunha, J.M., 2019. Variabilidade espacial da emissão de $\mathrm{CO}_{2}$, temperatura e umidade do solo em área de pastagem na região Amazônica, Brasil. Revista de Ciências Agroveterinárias, 18(1), 119-126.

Silva, G.V.C., Valentini, C.M.A., Faria, R.A.P.G., 2016. Respiração do solo de uma área revegetada de cerrado, em Cuiabá-MT. Ciência e Natura, 38(1), 432-442.

Silva, M.S.C.D., Silva, E.M.R.D., Pereira, M.G., Silva, C.F., 2012. Estoque de Serapilheira e Atividade Microbiana em Solo sob Sistemas Agroflorestais. Flora e Ambiente, 19(4), 431-441.
Soil Survey Staff, 2014. Keys to Soil Taxonomy, twelfth ed. Washington, DC: USDA-Natural Resources Conservation Service, Washington, DC.

Souza, E.D.D., Costa, S.E.V.G.D.A., Anghinoni, I., Lima, C.V.S.D., Carvalho, P.C.D.F., Martins, A.P., 2010. Biomassa microbiana do solo em sistema de integração lavoura-pecuária em plantio direto, submetido a intensidades de pastejo. Revista Brasileira de Ciência do Solo, 34(1), 79-88.

Trannin, I.C.B., Siqueira, J.O., Moreira, F.M.S., 2007. Características biológicas do solo indicadoras de qualidade após dois anos de aplicação de biossólido industrial e cultivo de milho. Revista Brasileira de Ciência do Solo, 31(5), 1173-1184. 